\title{
Portrayal of Ecological Crisis In Indonesian Prose: Fiction and Reality
}

\author{
R Rahmayati ${ }^{1}$, R Rengganis ${ }^{2}$, T Tjahjono $^{3}$ \\ Indonesian Language and Literature Department, Language and Art Faculty, Universitas \\ Negeri Surabaya, Indonesia \\ rahmirahmayati@unesa.ac.id
}

\begin{abstract}
This research describes the ecological crisis that occurred in Indonesia which is represented in Indonesian prose and its relation to the reality of the ecological crisis that occurred in Indonesia. This research is important because prose as a literary work can portray the reality of the ecological crisis that occurred in Indonesia. The prose is Indonesian prose which published in the range 2011-2016. The analysis was conducted based on the study of ecocriticism. Based on the results of the study, the ecological crisis that occurred in Indonesia was represented in Indonesian prose. The ecological crisis occurs because of the anthropocentric perspective and human attitude towards nature/environment. This anthropocentric attitude is demonstrated by excessive exploitation of natural resources which results in the ecological crisis of forests, destruction of karst, and river water pollution (rivers and seas) that occur in parts of Indonesia (Java, Sumatra, Sulawesi), Kalimantan and West Nusa Tenggara).
\end{abstract}

Keywords: Data Security, Ecology, portrayal

\section{INTRODUCTION}

The ecological crisis is becoming a global problem nowadays. This is because environmental destruction occurs not only in one place or in one country, but in some places or countries, especially in industrialized countries. It is as said Syarief and Sarna [1] that global environmental destruction began to be felt since the birth of the industrial revolution in Europe which was followed by several other industrialized countries. Nevertheless, the level of global environmental destruction is increasingly high and rapidly intensity in the 1950s after humankind has the ability to exploit natural resources in very large quantities.

The ecological crisis began to be voiced since the 1960s, where most people began to rethink their relationship to nature when humans' action begins to threaten the balance of nature and alienate humans with life other than themselves. At its peak, in the 1980s, almost certainly everyone's awareness was sucked into the problem, even scientific articles that discussed this issue increased sharply.[2]

Indonesia as one of the industrialized countries is one of the major contributors in the extinction of biodiversity, global warming, and the destruction of marine ecosystems. Besides, Indonesia is considered the largest forest destroyer in the world because the level of forest destruction in Indonesia is very high [1] In fact, according to Greenpeace, about 70 percent of the environmental destruction in Indonesia is caused by mining.[1] Based on this, Indonesia is experiencing an ecological crisis. 
The reality of the ecological crisis in Indonesia is illustrated in Indonesian prose (novels and short stories) published in the range 2011-2016. These prose besides raising the issue of ecological crisis, also discussed the attitude (impartiality) of government to the interests of the environment, anthropocentric and environmentally destructive behavior. The ecological crisis described in these prose is the destruction of forests, karst, valleys, hills, mountains, coral reefs, seas, flora and fauna, and river water pollution that occur on various islands in Indonesia, including Java, Sumatra, Sulawesi, Kalimantan, and West Nusa Tenggara.

The ecological crisis occurs due to excessive exploitation of natural resources through illegal logging, oil drilling, mining (limestone, coal, sea sand), the establishment of factories and housing/villas, deforestation/eviction of forests, and a bombing of coral reefs. This is because of human attitudes that more prioritize their interests than the interests of the environment. This attitude is based on the human perspective on nature which tends to be anthropocentric, namely, the perspective that human interests are more important than natural interests as expressed by Buell [3] that anthropocentrism is the assumption or that the interests of humans are of higher priority than those of nonhumans.

Literary work (in this case prose) is a reflection of a reality that can represent things that exist or occur around them, including describing the ecological crisis. Literary works that analyzed/studied based on ecological perspectives are ecocritical studies. The ecocritical study is an interdisciplinary and multidisciplinary study because it combines two disciplines, namely ecology and literature. This was confirmed by Harsono [4] that ecocritical theory is multidisciplinary, on the one hand, ecocriticism uses literary theory and on the other hand, uses ecological theory.

The term ecocriticism was possibly first coined in 1978 by William Rueckert in his essay "Literature and Ecology: An Experiment in Ecocriticism." By ecocriticism, Rueckert meant "the application of ecology and ecological concepts to the study of literature." [5] Meanwhile, Glotfelty [5] argues that ecocriticism is the study of the relationship between literature and the physical environment. Besides, ecocriticism can be further characterized by distinguishing it from other critical approaches. Literary theory, in general, examines the relations between writers, texts, and the world. In most literary theory "the world" is synonymous with societythe social sphere. Ecocriticism expands the notion of "the world" to include the entire ecosphere. [5]

In 1980 an article emerged that applied ecocriticism in literary works related to nature and environmental problems. In the early 1990 s, ecocriticism was widely used as an approach in literary research, especially in America.[6] [7]

In terminology, ecocriticism wants to trace ideas about the environment and its representation [8] Correspondingly, in the area of literary theory, an ecocritical theory can be traced to the paradigm of mimetic theory which has a basic assumption that literature is related to reality. [9]

Based on this, the problems that will be discussed in this paper are 1) How ecological crisis in Indonesia reflected on prose?; 2) How causes the ecological crisis in Indonesia reflected on prose?

\section{METHOD}

Methodology in this research used a qualitative descriptive method. The method was used to describe the ecological crisis in Indonesia that reflected on prose and to describe the causes of the ecological crisis in Indonesia which reflected on prose. 
The method in this research includes four stages: 1) data collection and classification, 2) data analysis, 3) data interpretation, and 4) conclusion of data result. First, data collection and classification were done by collecting the primary data (Indonesian prose) and the secondary data (documentation contained in newspaper articles, magazines, or journals that describe the environmental crisis that occurred in Indonesia and studies that link the reality of the environment and literary work). Then, the data were classified based on the problems of the study.

Second, the data analysis was done by analyzing the data that has been classified based on problems of the study by using eco-criticism study. Third, the data interpretation was done by interpreting the results of data analysis based on the eco-criticism study. Fourth, the conclusion of the data obtained by concluding the results of data based on data analysis and interpretation.

\section{RESULT AND DISCUSSION}

The ecological crisis that occurred in Indonesia included the destruction of forests, valleys, hills, mountains, karsts, coral reefs, trees and plants, pollution of river and seawater, and the extinction of species. The ecological crisis is represented in Indonesian prose that published in 2011-2016, including Qozan by Imogail Zam-zami Djalaludin published in 2011, Pincalang by Idris Pasaribu published in 2012, Ki Pawon short story by Heri Nurdiansyah published in 2013, Lais by Nenden Lilis published in 2013, Ayat Suci yang Menari by Garina Adelia published in 2014, Dari Rahim Ombak by Tison Sahabuddin Bungin published in 2015, Baiat Cinta di Tanah Baduy by Uten Sutendy published in 2015, Jeritan Tengah Malam short story by Makhfud Ikhwan published in 2016, and Kelomang by Qizink La Aziva published in 2016. In this paper, the discussion focuses on mountain and karst destruction and water pollution.

Based on data from the Forestry Planning Agency, the overall state of Indonesia's natural forests can be categorized as one of the crises facing this nation. The annual deforestation rate of one million hectares has persisted throughout the last ten years and the installed capacity of the wood processing industry continues to grow beyond the annual sustainable utilization rate.[10]

Besides, according to The Center for International Forestry Research (CIFOR's) report, the average deforestation in Indonesia reaches 1.7 million hectares per year. The World Bank in its 2000 report predicted that land conversion and deforestation reached 2 million hectares per year. Also, the World Research Institute (1992) revealed that Indonesia currently had lost more than $72 \%$ of the potential of natural forests, which means an average loss of 3.4 million hectares every year.[1] Meanwhile, official government data said, from the 144 million hectares of forest area in the 1950s it had shrunk to 92.4 million hectares by the end of this year. [11] It is ironic, Indonesia is a country categorized as a megadiversity country with Brazil and Colombia, but at the same time it is also recorded as a country with the highest level of forest destruction and destruction of diversity in the world.[1]

The reality of the forest crisis is reflected in Qozan by Imogail Zam Zami Djalaluddin, Pincalang by Idris Pasaribu, Sarongge by Tosca Santoso, Ayat Suci yang Menari by Garina Adelia, Baiat Cinta di Tanah Baduy by Uten Sutendy, and Kelomang by Qizink La Aziva.

The forest crisis that described in the prose is destruction to wilderness, peat forest, sago forest, mangrove forest, and teak forest. This crisis was caused by illegal logging, the establishment of villas/housing, oil drilling, forest fires and forest narrowing due to deforestation and forest evictions that occurred in Central Sulawesi, Java Island, Kalimantan Island, Maluku Islands and Sumatra Island. This is as the following quotations. 
Ia teringat dengan kepanikan warga sukunya terhadap kebiadaban orang-orang yang tak bertanggung jawab. Orang-orang yang melakukan pembalakan liar di wilayah kesukuannya yang penuh kekentalan adat. Orang-orang yang tengah mencabik-cabik nurani warga sukunya, memisahkan pikiran mereka terhadap kepedulian hutan menurut aturan adat sukunya dengan pemikiran modern.[12]

In the above quote, the panic of the interior tribes of Central Sulawesi is described because of the behavior of outsiders (tribal tribes) who carry out illegal logging in the forests they inhabit since their ancestors were still there. Inland tribesmen who have always adhered to local wisdom have been disturbed by outsiders who want to exploit natural resources by carrying out illegal logging for personal interests or certain groups of people. This shows that the forest crisis has occurred in the interior of Central Sulawesi due to illegal logging.

Forest destruction is also represented in the novel Pincalang by Idris Pasaribu. In this novel, the forest crisis described is the destruction of mangrove forests due to indiscriminate logging of mangrove trees, causing deforestation of mangrove forests. In addition, it was also described that destructionto mangrove forests occurred in all mangrove forests in Sibolga, North Sumatra. This is as described in the following quotations.

Bersama Sangkot dan Lokot, Amat kembali ke pulau yang biasa mereka tempati memasak minyak makan, membuat arang, dan menjemur ikan asin. Ketika melintasi pulau-pulau, amat ingin menjerit melihat semua hutan bakau sudah gundul. Sudah setahun lebih tak ada lagi yang mengambil pohon bakau. Bahkan pabrik arang juga sudah tutup karena ketiadaan bahan baku.[13]

Forest damage is also reflected in Tosca Santoso's Sarongge novel. In the novel, the damage to sago forests is described as being converted into oil palm, corn, sugar cane or rice fields. Also, the clearing of peat forests is also described to be functioned as oil palm plantations on Java, Sumatra, Kalimantan, and Papua. This is by the following quote.

"Cara itu berjalan baik, tanpa masalah, sebelum banyak investor masuk mengkaplingkapling hutan sagu. Pemodal yang tak sabaran, ingin segera mengeruk untung, mengubah hutan sagu jadi kebun kelapa sawit, jagung, tebu atau padi. Proyek Merauke untuk Pangan dan Energi, mengusir warga Marind dari akar hidup mereka [14]

Riwayat orang kecil memang sama, di mana saja. Mereka jadi korban yang pertama. Dan, tragisnya hutan gambut mereka juga tak bisa dikembalikan lagi. Yang paling buruk dari cerita ini: keserakahan membabat hutan itu terus berlangsung sampai kini. Hanya sasaran lokasinya yang berpindah. Dulu Jawa dan Sumatra, lalu Kalimantan, dan sekarang keserakahan bergeser ke Papua." [14]

"Nicholas tertegun. Berarti masalah di tambang ini bukan sekadar perusakan hutan untuk eksplorasi tambang, tapi upaya meruntuhkan sebagian besar permukaan bumi hanya untuk mengeruk isinya. Ini bukan sekadar labu yang dikeruk dalamnya untuk dijadikan hiasan dalam acara Halloween - seperti yang dulu pernah dibahasnya dengan Laura. Namun inilah pengerukan besar-besaran yang mungkin akan membahayakan kehidupan manusia di bumi secara universal." [15]

Excerpts in the novel Ayat Suci yang Menari by Garina Adelia above describe Nicholas's thinking about forest destruction in Kalimantan was not just for mining exploration, but also an effort to dredge the contents of the earth which would endanger human life on earth universally. This shows that forest destruction occurs on a large scale, which is not just for mining exploration, but also exploitation of the earth's resources excessively.

Representation of forest destruction is also described in the novel Baiat Cinta di Tanah Baduy by Uten Sutendy. The forest destruction that described in this novel was caused by oil 
drilling carried out by the oil company PT Banten Nusantara Energy in collaboration with foreign company Sweden Petroleum and supported by officials in Banten. This is as illustrated in the following quotations.

"Kami mohon kepada pemerintah supaya meninjau ulang izin pengeboran minyak di wilyah tanah Baduy dan Ujung Kulon. Kalau bisa, benar-benar dihentikan, karena berdampak serius kepada keutuhan dan keseimbangan ekosistem hutan. "[16]

In the quotations above, it is illustrated that oil drilling in Baduy and Ujung Kulon has disrupted and damaged the integrity and balance of forest ecosystems.

Besides the forest crisis, karst destruction also occurs in Indonesia. Karst destruction in Indonesia occurs in several regions in Indonesia, one of which is in West Java. West Java's Walhi (Wahana Lingkungan Hidup) Executive Director, Dadan Ramdan, said that as many as 40 percents of the 58,000 hectares of karst in the West Java region had been damaged due to mining activities. Karst destruction expanse is located in Citatah, Cibinong, Mount Goha Sukabumi, Mount Kromong, and District of Pangkalan Karawang. [17]

Karst destruction in West Java described in the paragraph above was represented in $\mathrm{Ki}$ Pawon's short story by Heri Nurdiansyah. In the short story, it was described that environmental damage (damage to hills and karst) occurred in West Java due to limestone mining, both by companies and by individuals (some communities). This is as the following quote.

"Datanglah ke desaku sekarang! Bersiaplah melupakan bayangan kalian tentang desaku yang elok dan memesona itu. Relakanlah bayangan kalian tertiup hembusan angin yang bercampur dengan pekatnya debu-debu batu kapur atau bahkan tercabikcabik oleh pongahnya tangan bercakar bulldozer backhoe, seperti tercabik-cabiknya bongkahan-bongkahan batu kapur di bukit-bukit karst itu." [18]

Ki Pawon's short story excerpt, describes the destruction of hills and karst for limestone mining using modern equipment such as a backhoe bulldozer.

Water pollution is also an environmental problem in Indonesia. Water pollution in Indonesia does not only occur in urban areas but also in rural areas. Among them is water pollution in West Java, namely Citarum River and river water pollution in Serang, Banten.

Parikesit revealed that In Indonesia, especially in the province of West Java which is the center of modern textiles and the fashion industry, many manufacturing plants operate, for example in the Bandung area. The existence of the textile industry in this area has contributed to the pollution of the Citarum River. Even though the problem of unmanaged domestic wastewater and visible waste is seen to be severe, industrial waste is also an important cause of river pollution. The quantity of industrial waste is claimed to be less than domestic waste, but based on the study of industrial wastewater it is more concentrated and contains a lot of hazardous materials. For example, a 2005 study of sources of water pollution in the upper reaches of the Citarum River found that pollution was mostly caused by industrial activities in the upstream parts of the river.[19]

Also, water pollution also occurs in Banten Bay waters due to sea sand mining. Banten Bay waters have been polluted which indicates an increase in suspended solids or Total Suspended Solid (TSS) to exceed the environmental quality threshold. Sea sand mining activities hurt the marine ecosystem, in the form of seawater pollution (turbidity) in Banten Bay. The turbidity of Banten Bay waters that have exceeded the quality standard can affect phytoplankton photosynthesis in the waters of Banten Bay so that it can inhibit its growth and also affect another biota because phytoplankton is primary productivity of a life cycle in the marine environment.[20]

Water pollution in West Java is represented in Lais's short story by Nenden Lilis and Kelomang novel by Qizink La Aziva. In the short story of Lais by Nenden Lilis represents 
damage to the river that occurred in West Java due to the establishment of a chemical factory. This is explained in the following quotations.

"Air yang bersih dan bening, bukan air sungai di kampungku yang mengalirkan segala kekotoran dan kejorokan. Bukan air yang membawa limbah-limbah penyakit buangan rumah sakit yang berada tidak jauh dari tempatku mengontrak kamar sempit di bantaran sungai itu. Juga limbah bermacam pabrik yang membuat air sungai berwarna-warni. Aku tidak sedang berada di sana. " [18]

In addition, water pollution in Banten is represented in Kelomang by Qizink La Aziva as quoted below

"Nelayan memiliki hak untuk menikmati laut yang asri sebagai tempat mereka mencari nafkah. Penambangan pasir laut bisa berdampak buruk terhadap lingkungan tempat nelayan mencari nafkah, biota laut akan mati karena laut keruh. Saudara-saudara yang hidup di pinggir pantai dan berprofesi nelayan tentu tak rela jika tempat mereka mencari nafkah dirusak...!'”21]

In the novel, it is described that sea sand mining can have a negative impact on the existence of the sea because it will result in cloudy sea and dead marine life.

Syarief [1] expressed that the cause of the threat of sustainability and biodiversity is a direct result of uncontrolled exploitation of nature and more and more massive areas and numbers. Real examples of exploitation and actions include:

Conversion of forest land for certain purposes

Jusmaliani stated that forest destruction tends to be accompanied by a decrease in forest cover due to forest function shifts (deforestation), both for residential settlements and for expansion agricultural and plantation area. [22]

The conversion of forest land to be used as a settlement is reflected in Indonesian prose, namely Sarongge by Tosca Santoso and Jeritan Tengah Malam (short story) by Ikhwan Mahfud. In the novel Sarongge it is described that the Bakrie Company devoured thousands of hectares to build a housing complex (page 53). So even in the short story of Jeritan Tengah Malam, it was described as forest conversion function for housing. (page 26)

The conversion of forest land for oil palm plantations is represented in Sarongge. In the novel it is told about the conversion of sago forests and peat forests to establish oil palm plantations. (page 18, 90,91)

The conversion of forest land for forest logging concessions is depicted in Sarongge by Tosca Santoso. In the novel, forest logging was initially carried out on Java and Sumatra, then shifted to Kalimantan to Papua (pages 90-91).

The conversion of forest land for forest burning purposes is also described in Sarongge's novel. In this prose, forest burning is carried out in Papua to convert the function of peat forest land into oil palm plantations and industrial interests. (page 18).

Utilization of forest land use functions for clearing mining land is described in Ayat Suci yang Menari by Garina Adelia and Baiat Cinta di Tanah Baduy by Uten Sutendy. In the novel Ayat Suci yang Menari, the conversion of forest land is used for the opening of coal mining land (page 14). As for the novel Baiat Cinta di Tanah Baduy over the function of forest land is used for clearing oil drilling (page 168).

The conversion of forest land used for poaching is described in Qozan by Imogail Zam-zami Djalaluddin and Ki Pawon short stories by Herry Nurdiansyah. In the Qozan novel, the conversion of forest land is carried out for the personal benefit of irresponsible people (page 275). So even in Ki Pawon short stories (pages 96 - 97). 


\section{CONCLUSION}

The ecological crisis depicted in Indonesian prose reflects the ecological crisis occurring in Indonesia. The ecological crisis includes the destruction of forests, karst, river water pollution.

The causes of the ecological destruction described in Indonesian prose represent the causes of ecological damage occurring in Indonesia. These include settlement, large-scale agriculture such as oil palm, forest logging concessions, forest burning, mining land clearing, Illegal acts, such as illegal logging, illegal mining.

\section{REFERENCES}

[1] L. M. Syarief, Hukum Lingkungan: Teori, Legislasi, dan Studi Kasus. Jakarta: USAID, kemitraan partnership, The Asia Foundation, 2014.

[2] Amirullah, "Krisis Ekologi: Problematika Sains Modern," Lentera, vol. XVIII, no. 1, pp. 1-149, 2015.

[3] L. Buell, The future of environmental criticism: environmental crisis and literary imagination. New Jersey: Blackwell Publishing, 2005.

[4] S. Harsono, "Ekokritik : Kritik Sastra Berwawasan Lingkungan," Ekokritik, vol. 32, no. 1, pp. 31-50, 2008.

[5] C. Glothfelty and H. Froom, The Ecocriticism Reader: Landmarks in Literary Ecology. London: University of Goergia Press, 1996.

[6] G. Greg, Ecocriticism. London and New York: Routledge, 2004.

[7] J. K, "Manusia dan Lingkungan dalam Life In The Iron Mills Karya Rebecca Hardings Davis," Litera, vol. 11, no. 1, pp. 83-97, Jan. 2013.

[8] R. Kerridge and N. Sammells, Writing The Environment. London: Zed Books, 1998.

[9] R. Wellek and A. Warren, Theory of Literature. Harmondsworth: Penguin Books, 1963.

[10] A. Contreras-hermosilla and C. Fay, Memperkokoh Pengelolaan Hutan Indonesia melalui Pembaruan Penguasaan Tanah. Bogor: World Agroforestry Centre, 2006.

[11] N. M. Heriyanto, E. Subiandono, and A. Tenggara, "Status Kelangkaan Jenis Pohon di Kelompok Hutan Sungai Lekawai-Sungai Jengonoi , Sintang, Kalimantan Barat,” Bul. Plasma Nutfah, vol. 9, no. 2, pp. 28-37, 2003.

[12] I. Z. Djalaluddin, Qozan. Jakarta: Republika, 2011.

[13] I. Pasaribu, Pincalang. Jakarta: Salsabila Pustaka Al-Kautsar, 2012.

[14] T. Santoso, Sarongge. Jakarta: Dian Rakyat, 2012.

[15] G. Adelia, Ayat Suci yang Menari. Jakarta: Gramedia Pustaka Utama, 2014.

[16] U. Sutendy, Baiat Cinta di Tanah Baduy. Jakarta: PT Adhi Kreasi Pratama Komunikasi, 2015.

[17] D. Rihanto, "Walhi: 40\% Karst di Jabar Rusak Akibat Tambang," Pikiran Rakyat, 2017. [Online]. Available: https://www.pikiran-rakyat.com/jawa-barat/2017/04/02/walhi-40karst-di-jabar-rusak-akibat-tambang-397802.

[18] S. Sastro, Antologi Cerpen Indonesia-Malaysia. Jakarta and Malaysia: Yayasan Pustaka Obor Indonesia dan Institut Terjemahan dan Buku Malaysia., 2013.

[19] D. M. Putra, "Kontribusi Industri Tekstil dalam Penggunaan Bahan Berbahaya dan Beracun terhadap Rusaknya Sungai Citarus," J. Huk. Lingkung., vol. 3, no. 1, pp. 133 $152,2016$.

[20] Z. Ernas, M. H. Thayib, and W. S. Pranowo, "Pengaruh Penambangan Pasir Laut Terhadap Kekeruhan Perairan Teluk Banten Serang,” J. Segara, vol. 14, no. 1, pp. 3542, Sep. 2018. 
[21] Q. La Aziva, Kelomang. Jakarta: Gramedia Pustaka Utama, 2016.

[22] Oksana, M. Irfan, and M. U. Huda, "Pengaruh alih fungsi lahan hutan menjadi perkebunan kelapa sawit terhadapsifat kimia tanah," J. Agroteknologi, vol. 3, no. 1, pp. 29-34, 2012. 